\title{
Expression and clinical significance of colorectal cancer stem cell marker EpCAM ${ }^{\text {high }} / \mathrm{CD} 4^{+}$in colorectal cancer
}

\author{
DAN LIU ${ }^{1}$, JINGHUA SUN $^{1}$, JINMING ZHU ${ }^{2}$, HUAN ZHOU $^{1}$, XIAN ZHANG $^{1}$ and YANG ZHANG ${ }^{1}$ \\ ${ }^{1}$ Department of Oncology, The Second Affiliated Hospital of Dalian Medical University, Dalian, Liaoning 116027; \\ ${ }^{2}$ Department of Oncology, Affiliated Zhongshan Hospital of Dalian University, Dalian, Liaoning 116001, P.R. China
}

Received July 18, 2013; Accepted January 15, 2014

DOI: $10.3892 / \mathrm{ol} .2014 .1907$

\begin{abstract}
Colorectal cancer stem cells are considered the source of recurrence, metastasis and drug resistance in colorectal tumors. Therefore, the identification and targeting of cancer stem cells facilitates the elimination of tumors. Although epithelial cell adhesion molecule-high $\left(\right.$ EpCAM $\left.{ }^{\text {high }}\right) /$ cluster of differentiation $(C D) 44^{+}$cells are thought to act as a marker of colorectal cancer stem cells, the clinical significance of these cells in colorectal cancer remains unclear. The aim of the present study was to explore the prevalence and clinical significance of colorectal cancer stem cell marker EpCAM ${ }^{\text {high }} / \mathrm{CD}_{4} 4^{+}$in colorectal cancer. Double immunohistochemical staining was used to detect the expression of EpCAM/CD44 in 80 cases of colorectal cancer and their corresponding liver metastases. The expression of EpCAM/CD44 in colorectal cancer was analyzed, and the correlation of EpCAM ${ }^{\text {high }} / \mathrm{CD} 44^{+}$with the biological behavior of colorectal cancer was explored. In the 80 cases of colorectal cancer studied, the presence of EpCAM ${ }^{\text {high }} / \mathrm{CD} 44^{+}$cells had no correlation with gender, patient age or the magnitude of the tumor $(\mathrm{P}>0.05)$, but was significantly correlated with degree of differentiation, depth of invasion, clinical stage and metastatic status $(\mathrm{P}<0.05)$. In addition, EpCAM ${ }^{\text {high }} / \mathrm{CD} 44^{+}$cells were detected in the corresponding liver metastases. Thus, the results of this study indicate that EpCAM ${ }^{\text {high }} / \mathrm{CD} 44^{+}$, a marker of colorectal cancer stem cells, is significantly correlated with the invasion and metastases of colorectal cancer.
\end{abstract}

\section{Introduction}

Colorectal cancer is one of the most common types of cancer and the second greatest cause of cancer-associated

Correspondence to: Professor Yang Zhang, Department of Oncology, The Second Affiliated Hospital of Dalian Medical University, 467 Zhongshan Road, Dalian, Liaoning 116027, P.R. China

E-mail: zydl@medmail.com

Key words: colorectal cancer, double immunohistochemical staining, EpCAM ${ }^{\text {high }} / \mathrm{CD} 44^{+}$, stem cells mortality in the United States (1). Epidemiological investigation has revealed the highest incidence of colorectal cancer in North America and Australia, suggesting it is a disease associated with lifestyle (1). With changing diet in China, the incidence and mortality of colorectal cancer are increasing markedly. Although surgical resection, radiotherapy, chemotherapy and targeted therapies are available for the treatment of colorectal cancer, recurrence and metastasis (20-40\% of patients present with liver metastases at diagnosis) remain a cause of poor prognosis.

It has been proposed that a small group of cells exists in tumors with properties of stem cells, including self-renewal, multilineage differentiation, multidrug resistance and tumorigenesis. These cells are considered cancer stem cells and the source of the recurrence and metastasis of colorectal cancer (2,3). Previous studies have revealed that epithelial cell adhesion molecule-high (EpCAM $\left.{ }^{\text {high }}\right) /$ cluster of differentiation (CD) $44^{+}$colorectal cancer cells have such stem cell-like properties, leading to tumorigenesis, invasion and metastasis of colorectal cancer (4-6). This suggests that EpCAM ${ }^{\text {high }} / \mathrm{CD}_{4} 4^{+}$ may be used as a marker of colorectal cancer stem cells (4).

In order to further understand the clinical significance of EpCAM ${ }^{\text {high }} / \mathrm{CD}_{4} 4^{+}$colorectal cancer cells, the present study used double immunohistochemical staining to detect the presence of EpCAM ${ }^{\text {high }} / \mathrm{CD} 44^{+}$cells in 80 cases of colorectal cancer and 10 cases of corresponding liver metastases to explore the correlation between these cells and the biological behavior of colorectal cancer.

\section{Materials and methods}

Patients and tissue samples. Clinical data were collected from medical records at the First and Second Affiliated Hospitals of Dalian Medical University (Dalian, China). Formalin-fixed paraffin-embedded tumor samples from 80 cases of colorectal cancer and 10 cases of corresponding liver metastases obtained between 2003 and 2010 were used in this study. In total, 30 cases of normal intestinal mucosa were used as the controls. Paraneoplastic intestinal mucosa samples were used as controls. There were 38 male cases and 42 female cases. Patient age ranged between 19 and 83 years (mean age, 60 years), and 44 cases were $>60$ years old and 36 were $\leq 60$ years old. Tumor diameter in 30 cases was $>5 \mathrm{~cm}$ and $<5 \mathrm{~cm}$ in 50 cases. Histologically, there were 
10 highly differentiated, 51 moderately differentiated and 19 poorly differentiated cases. According to tumor, lymph node and metastasis (TNM) staging, 18 cases were stage T1 or T2, 28 cases were T3 and 34 cases were T4. Dukes' staging described 16 cases of Dukes' A, 16 cases of Dukes' B, 22 cases of Dukes' $\mathrm{C}$ and 26 cases of Dukes' D. Metastases were present in 48 cases and absent in 32.

All histological diagnoses were independently confirmed by two experienced pathologists. No patient had received chemotherapy or radiotherapy prior to surgery. All tumors were classified using the 2010 criteria of the World Health Organization (WHO) (7,8). The study was approved by the Regional Ethics Committee of Dalian Medical University and performed in accordance with the Declaration of Helsinki. Patients provided written informed consent.

Double immunohistochemical staining. Embedded specimens were sectioned at a thickness of $4 \mu \mathrm{m}$. Double immunohistochemical staining was performed according to DouSP ${ }^{\mathrm{TM}}$ double staining kit (MaiXin Bio, Fuzhou, China) procedures. Following deparaffinization and dehydration, endogenous peroxidases were blocked briefly with $3 \% \mathrm{H}_{2} \mathrm{O}_{2}$. Non-specific antibody binding was blocked with goat serum for $10 \mathrm{~min}$ at room temperature. Sections were sequentially incubated with primary antibody [mouse anti-human EpCAM monoclonal antibody (MaiXin Bio)] overnight at $4^{\circ} \mathrm{C}$, followed by the secondary antibody [goat anti-mouse/rabbit polyclonal IgG (MaiXin Bio)] for $15 \mathrm{~min}$ at room temperature. Sections were incubated with alkaline phosphatase for $15 \mathrm{~min}$ at room temperature. EpCAM was detected with 5-bromo-4-chloro-3-indolyl phosphate, $p$-toluidine salt (BCIP)/nitro blue tetrazolium (NBT) at room temperature. Positively stained cells exhibited a blue-black precipitate in the cytoplasm. Sections were subsequently incubated with double staining enhancement solution for $10 \mathrm{~min}$ at room temperature, then blocked with goat serum for $10 \mathrm{~min}$, also at room temperature. Sections were then sequentially incubated with primary antibody [rabbit anti-human CD44 polyclonal antibody (Proteintech Group, Inc., Chicago, IL, USA)] overnight at $4^{\circ} \mathrm{C}$ and secondary antibody [goat anti-mouse/rabbit IgG (MaiXin Bio)] for $15 \mathrm{~min}$ at room temperature. CD44 was detected with aminoethylcarbazole (AEC) at room temperature. Positively stained cells exhibited red precipitate in the cytomembrane. In order to prove the reliability of double staining of $\mathrm{EpCAM}^{\text {high }} / \mathrm{CD} 44^{+}$, immunohistochemical staining of $\mathrm{EpCAM}^{\text {high }} / \mathrm{CD}_{4} 4^{-}, \mathrm{EpCAM}^{\text {low }} / \mathrm{CD}_{4} 4^{+}$and $\mathrm{EpCAM}^{\text {low }} / \mathrm{CD} 44^{-}$, respectively were used as controls.

Assessment of double immunohistochemical staining. $\mathrm{EpCAM}^{\text {high}} / \mathrm{CD} 44^{-}$cells were positive for BCIP/NBT staining but negative for $\mathrm{AEC}$ staining; $\mathrm{EpCAM} \mathrm{M}^{\text {low }} / \mathrm{CD} 44^{+}$cells were negative for BCIP/NBT staining but positive for $\mathrm{AEC}$ staining; EpCAM ${ }^{\text {low }} / \mathrm{CD}^{-} 4^{-}$cells were negative for the two stains; and EpCAM ${ }^{\text {high }} / \mathrm{CD} 44^{+}$cells were positive for the two stains (Fig. 1). The results were assessed according to Lin et al (9). Briefly, CD44 staining was detected mainly in the membrane and EpCAM staining was detected mainly in the cytoplasm. The results of EpCAM/CD44 cells proportion were classified into four groups, EpCAM ${ }^{\text {high }} / \mathrm{CD}_{4} 4^{+}$, $\mathrm{EpCAM}^{\text {high }} / \mathrm{CD} 44^{-}, \mathrm{EpCAM}^{\text {low }} / \mathrm{CD} 44^{+}, \mathrm{EpCAM}^{\text {low }} / \mathrm{CD} 44-$. The proportion of EpCAM ${ }^{\text {high }} / \mathrm{CD}_{4} 4^{+}$tumor cells were defined as the percentage of cells positive for both blue-black and red staining, EpCAM ${ }^{\text {high}} / \mathrm{CD}^{4} 4^{-}$were positve for blue-black staining [5-bromo-4chloro-3-indolyl phosphate, p-toluidine salt (BCIP)/nitro blue tetrazolium (NBT); MaiXin Bio], $\mathrm{EpCAM}^{\text {low }} / \mathrm{CD} 44^{+}$were positive for the red staining [3-amino 9-ethylcarbazole (AEC); MaiXin Bio] and EpCAM ${ }^{\text {low }} / \mathrm{CD} 44$ were negative for the two stains. The results of EpCAM ${ }^{\text {high/ }}$ $\mathrm{CD} 44^{+}$cells were based on the median value of their proportion checked for 10 visions under the microscope (BX51, Olympus Corporation, Tokyo, Japan). The labeling index (the percentage of positively stained cells) of each specimen was recorded and the values were averaged.

Statistical analysis. SPSS 17.0 (SPSS Inc., Chicago, IL, USA) was used for statistical analysis. Differences in the means of continuous variables between the groups were analyzed using analysis of variance or t-tests. P-values from two-tailed tests are reported and in all analyses $\mathrm{P}<0.05$ was considered to indicate a statistically significant difference.

\section{Results}

Expression of EpCAM/CD44 in samples of colorectal cancer and their corresponding liver metastases. Double immunohistochemical staining was used to detect the expression of EpCAM/CD44. The expression of EpCAM was predominantly cytoplasmic, whereas the expression of CD44 was primarily in the cytomembrane. EpCAM ${ }^{\text {high }} / \mathrm{CD}_{4} 4^{+}$ double-positive cells were not present in the normal intestinal mucosa adjacent to colorectal tumors (Fig. 2A). However, in samples of colorectal cancer and their corresponding liver metastases, EpCAM ${ }^{\text {high }} / \mathrm{CD} 44^{+}$cells were visible (Fig. 2B and 2C). Double-positive cells accounted for $0.8-3.1 \%$ of cells in colorectal tumors. The expression of EpCAM/CD44 was significantly correlated with degree of differentiation, tumor stage, depth of invasion (Dukes' stage) and metastatic status $(\mathrm{P}<0.05)$, while there was no correlation with gender, age or the magnitude of the tumor $(\mathrm{P}>0.05)$ (Table I).

\section{Discussion}

Cancer stem cells have the capacity for infinite proliferation and self-renewal, and account for $0.3-2.2 \%$ of colorectal cancer cells. They are considered the cause of recurrence, metastasis and drug resistance in tumors (8). Therefore the identification of cancer stem cells and treatments targeting these cells facilitates elimination of the tumor.

EpCAM, a 40 kDa glycoprotein, functions as an epithelial cell adhesion molecule (11); its expression has been reported as localized to the epithelium along the basolateral surface of the majority of gastrointestinal tract mucosa. EpCAM can inhibit differentiation and promote proliferation (12). It is expressed in $85 \%$ of colorectal carcinomas and is one of the earliest tumor markers to appear that is involved in signal transduction, regeneration of tissue and other biological functions. EpCAM can upregulate the expression of the oncogene c-myc, induce acceleration of the cell cycle and promote proliferation (12). The overexpression of EpCAM enhances the proliferative and invasive capacities of tumors, 

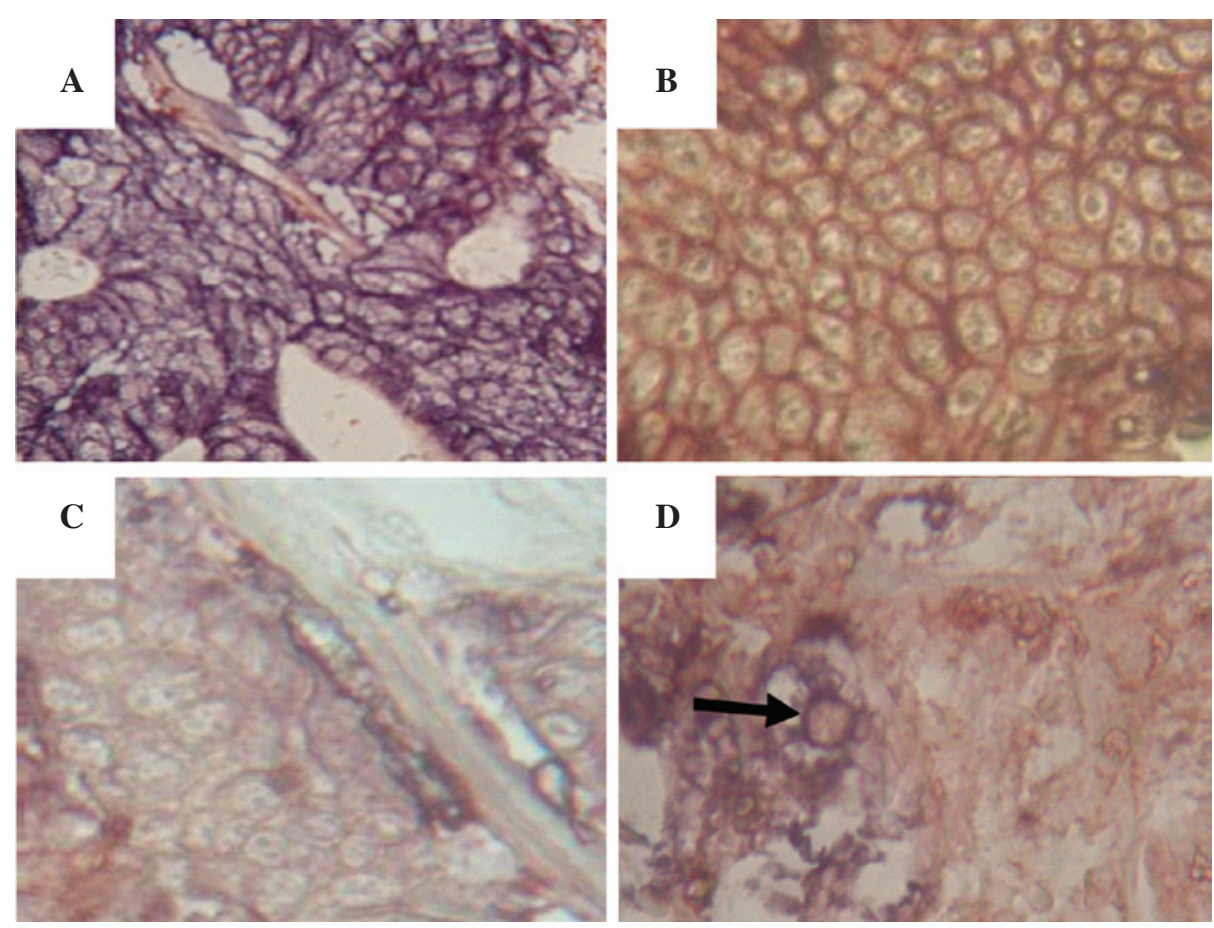

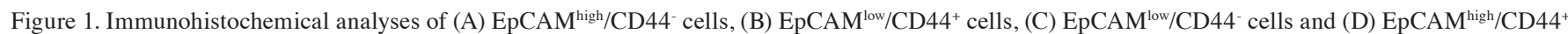
cells in colorectal cancer. Magnification, x400. EpCAM, epithelial cell adhesion molecule; CD44, cluster of differentiation 44.
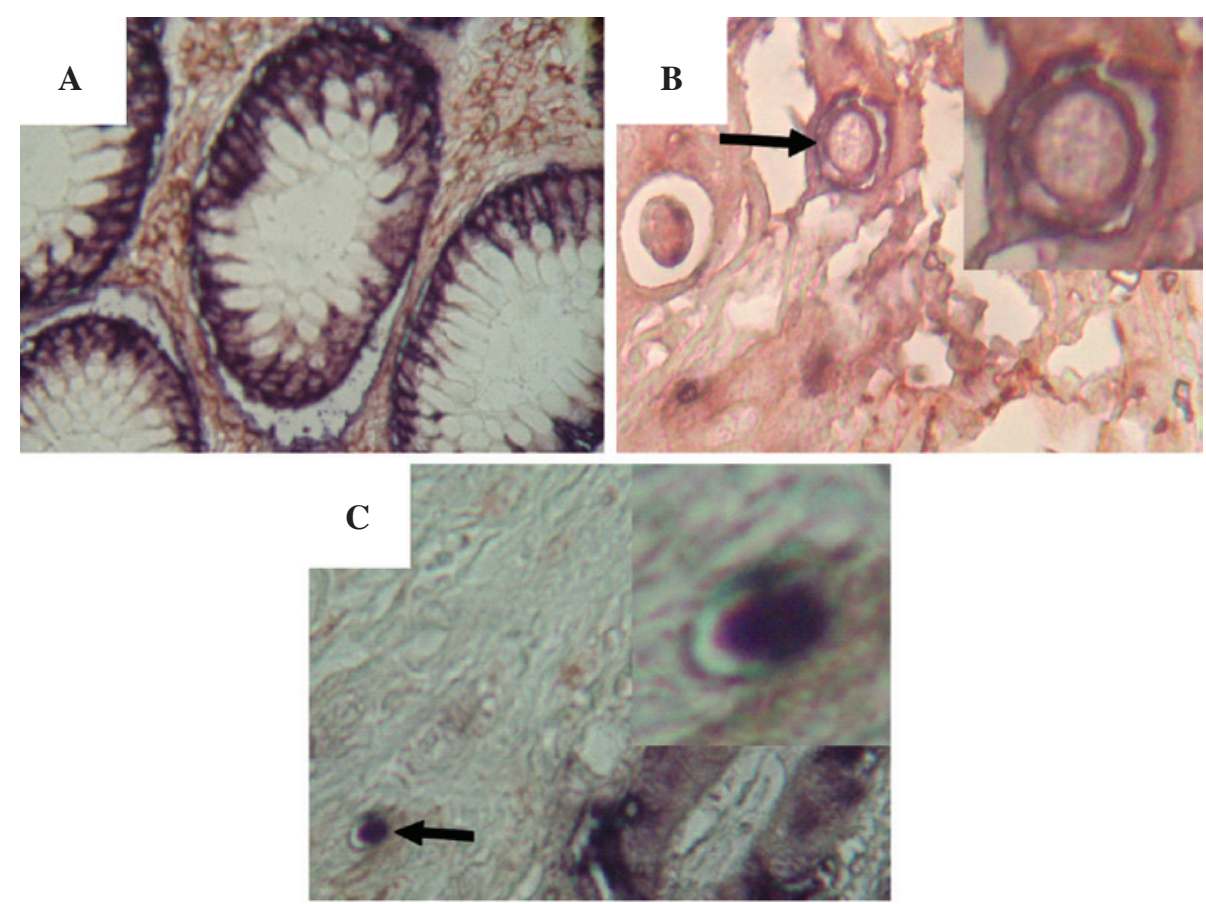

Figure 2. Double immunohistochemistry for EpCAM ${ }^{\text {high }} / \mathrm{CD}_{4} 4^{+}$cells showing (A) the absence of EpCAM ${ }^{\text {high }} / \mathrm{CD}_{4} 4^{+}$cells in normal intestinal mucosa, (B) $\mathrm{EpCAM}^{\text {high }} / \mathrm{CD} 44^{+}$cells in colorectal cancer and (C) $\mathrm{EpCAM}^{\text {high }} / \mathrm{CD} 44^{+}$cells in liver metastases. Magnification, $\mathrm{x} 400$. EpCAM, epithelial cell adhesion molecule; CD44, cluster of differentiation 44.

while downregulation by RNA interference inhibits these functions (13).

CD44 is a multifunctional class I transmembrane glycoprotein located on the cytomembrane $(14,15)$. As a cell adhesion molecule, CD44 is mainly involved in cell-cell and cell-matrix interactions (16). CD44 plays a vital role in the regulation of cell adhesion, growth, differentiation, migration and angiogenesis, and contributes to tumor progression by promoting invasion and metastasis $(14,15)$. Knockdown of CD44 in primary colon cancer cell lines reduces clonogenicity in vitro and tumorigenicity in vivo (17). Schulenburg et al isolated $\mathrm{CD} 44^{+}$and $\mathrm{CD} 44^{-}$cells from colon cancer samples. The authors found that $\mathrm{CD} 44^{+}$cells had characteristics of stem cells and showed much higher capacity for proliferation and 
Table I. Expression of EpCAM/CD44 in colorectal cancer.

\begin{tabular}{|c|c|c|c|}
\hline Variable & Samples, $\mathrm{n}$ & $\mathrm{EpCAM}^{\mathrm{high}} / \mathrm{CD} 44^{+}$cells, $\%$ & P-value \\
\hline Gender & & & 1.000 \\
\hline Male & 38 & $0.99 \pm 1.11$ & \\
\hline Female & 42 & $0.99 \pm 0.90$ & \\
\hline Patient age, years & & & 0.212 \\
\hline$>60$ & 44 & $0.84 \pm 1.04$ & \\
\hline$\leq 60$ & 36 & $1.12 \pm 0.96$ & \\
\hline Tumor magnitude, $\mathrm{cm}$ & & & 0.051 \\
\hline$\leq 5 \times 5$ & 50 & $0.80 \pm 0.73$ & \\
\hline$>5 \times 5$ & 30 & $1.31 \pm 1.29$ & \\
\hline Differentiation & & & $<0.001^{\mathrm{a}}$ \\
\hline High & 10 & $0.53 \pm 0.93$ & \\
\hline Moderate & 51 & $0.74 \pm 0.68$ & \\
\hline Low & 19 & $1.90 \pm 1.23$ & \\
\hline Tumor stage & & & $0.002^{\mathrm{a}}$ \\
\hline $\mathrm{T} 1+\mathrm{T} 2$ & 18 & $0.49 \pm 0.43$ & \\
\hline $\mathrm{T} 3$ & 28 & $0.80 \pm 0.43$ & \\
\hline $\mathrm{T} 4$ & 34 & $1.41 \pm 1.00$ & \\
\hline Dukes' stage & & & $<0.001^{\mathrm{a}}$ \\
\hline $\mathrm{A}$ & 16 & $0.42 \pm 0.39$ & \\
\hline $\mathrm{B}$ & 16 & $0.62 \pm 0.74$ & \\
\hline $\mathrm{C}$ & 22 & $0.89 \pm 0.66$ & \\
\hline $\mathrm{D}$ & 26 & $1.66 \pm 1.26$ & \\
\hline Metastasis & & & $<0.001^{\mathrm{a}}$ \\
\hline Negative & 32 & $0.52 \pm 0.59$ & \\
\hline Positive & 48 & $1.31 \pm 1.09$ & \\
\hline
\end{tabular}

${ }^{\mathrm{a}} \mathrm{P}<0.05$. EpCAM, epithelial cell adhesion molecule; $\mathrm{CD}$, cluster of differentiation.

invasion than CD44- cells (18). Thus, CD44 is considered a marker of cancer stem cells. In combination with other surface markers, CD44 can also be used to discriminate between a variety of cancer subsets (19).

Previous studies have revealed that the composite structure of EpCAM and CD44 can promote invasion and metastasis of tumors more strongly than any single adhesion molecule (20-22). In 2008, Marhaba et al proposed that $\mathrm{EpCAM}^{\text {high }} / \mathrm{CD} 44^{+}$cells are a marker of colorectal cancer stem cells (23), and Dalerba et al found that the EpCAM ${ }^{\text {high }} / \mathrm{CD} 44^{+}$ phenotype of colorectal cancer cells has stem cell-like properties (4). The authors reported that 200-500 EpCAM $\mathrm{Eph}^{\text {high }} / \mathrm{CD} 44^{+}$ cells promoted tumorigenesis in non-obsese diabetic/severe combined immunodeficient mice, while no tumor was produced by injection of $10^{4} \mathrm{EpCAM}^{\text {low }} / \mathrm{CD} 44^{-}$cells. Since the EpCAM ${ }^{\text {high }} / \mathrm{CD} 44^{+}$phenotype of colorectal cancer cells, which has stem cell-like properties, was confirmed (24), it has been regarded as an effective marker of colorectal cancer stem cells (25). The identification of cancer stem cells improves the understanding of tumorigenesis.

In the present study, 80 cases of colorectal cancer and their corresponding liver metastases were examined. EpCAM ${ }^{\text {high }} / \mathrm{CD}_{4} 4^{+}$cells were not present in the adjacent normal intestinal mucosa. However, in colorectal cancer tissue and their corresponding liver metastases, EpCAM ${ }^{\text {high }} / \mathrm{CD} 44^{+}$ cells were visible. The percentage of double-positive cells was $0.8-3.1 \%$ in colorectal cancer, which is consistent with a previous study (9). Further analysis found that the percentage of EpCAM ${ }^{\text {high }} / \mathrm{CD} 44^{+}$cells in poorly differentiated tumors was higher than that in highly or moderately differentiated tumors. In addition, the percentage of EpCAM ${ }^{\text {high }} / \mathrm{CD} 44^{+}$ cells in the T-stage 4 and Dukes' D groups or in cases of metastasis was higher than that at other stages or in the group without metastases. Statistical analysis revealed that EpCAM ${ }^{\text {high }} / \mathrm{CD}_{4} 4^{+}$correlated with degree of differentiation, clinical stage, depth of invasion and metastasis. These results demonstrate that EpCAM ${ }^{\text {high }} / \mathrm{CD}_{4} 4^{+}$expression is significantly correlated with invasion and metastasis, and confirm EpCAM ${ }^{\text {high }} / \mathrm{CD}_{4} 4^{+}$cells as effective markers for colorectal cancer stem cells. These findings support the proposal that cancer stem cells may be the cause of recurrence and metastasis.

Based on the theory that cancer stem cells are the source of tumorigenesis, recurrence and metastasis in tumors, targeting cancer stem cells should effect the elimination of tumors. Specific drugs (catumaxomab and edrecolomab) targeting 
EpCAM have been developed, which can significantly reduce the size of tumor used alone or in combination with standard treatment, demonstrating the potential of such targeting strategies $(26,27)$. Further study and the development of targeted drugs is required to elucidate the mechanisms of colorectal cancer stem cells and improve the clinical prognosis of colorectal cancer.

EpCAM ${ }^{\text {high }} / \mathrm{CD}_{4} 4^{+}$, which is regarded as a marker of colorectal cancer stem cells, is significantly correlated with the invasion and metastasis of colorectal cancer, suggesting that this molecular marker may promote the progression of tumors.

\section{Acknowledgements}

The skillful technical assistance of the Department of Pathology, The Second Affiliated Hospital of Dalian Medical University (Dalian, China) in preparing sections for immunohistochemistry is gratefully acknowledged. The authors thank laboratory members for help with photographic work.

\section{References}

1. Yamaki M, Shinozaki K, Sakaguchi T, Meseck M, Ebert O, Ohdan $\mathrm{H}$ and Woo SL: The potential of recombinant vesicular stomatitis virus-mediated virotherapy against metastatic colon cancer. Int J Mol Med 31: 299-306, 2013.

2. Christ B and Stock P: Mesenchymal stem cell-derived hepatocytes for functional liver replacement. Front Immunol 3: 168, 2012 .

3. Lakowski J, Han YT, Pearson RA, et al: Effective transplantation of photoreceptor precursor cells selected via cell surface antigen expression. Stem Cells 29: 1391-1404, 2011.

4. Dalerba P, Dylla SJ, Park IK, et al: Phenotypic characterization of human colorectal cancer stem cells. Proc Natl Acad Sci USA 104: 10158-10163, 2007.

5. Lugli A, Iezzi G, Hostettler I, et al: Prognostic impact of the expression of putative cancer stem cell markers CD133, CD166, CD44s, EpCAM, and ALDH1 in colorectal cancer.Br J Cancer 103: 382-390, 2010.

6. Piscuoglio S, Lehmann FS, Zlobec I, et al: Effect of EpCAM, CD44, CD133 and CD166 expression on patient survival in tumours of the ampulla of Vater. J Clin Pathol 65: 140-145, 2012.

7. Fléjou JF: WHO Classification of digestive tumors: the fourth edition. Ann Pathol 31: S27-S31, 2011 (In French).

8. Aust DE: WHO classification 2010 for the lower gastrointestinal tract: what is new? Pathologe 32: 326-331, 2011 (In German).

9. Lin Y, Zhong Y, Guan H, Zhang X and Sun Q: CD44 ${ }^{+} / \mathrm{CD} 24$ phenotype contributes to malignant relapse following surgical resection and chemotherapy in patients with invasive ductal carcinoma. J Exp Clin Cancer Res 31: 59, 2012.

10. Haraguchi $\mathrm{N}$, Inoue $\mathrm{H}$, Tanaka F, et al: Cancer stem cells in human gastrointestinal cancers. Hum Cell 19: 24-29, 2006.
11. Sankpal NV, Mayfield JD, Willman MW, Fleming TP and Gillanders WE: Activator protein 1 (AP-1) contributes to EpCAM-dependent breast cancer invasion. Breast Cancer Res 13: R124, 2011.

12. Lin CW, Liao MY, Lin WW, Wang YP, Lu TY and Wu HC: Epithelial cell adhesion molecule regulates tumor initiation and tumorigenesis via activating reprogramming factors and epithelial-mesenchymal transition gene expression in colon cancer. J Biol Chem 287: 39449-39459, 2012.

13. Gaiser MR, Lämmermann T, Feng X, et al: Cancer-associated epithelial cell adhesion molecule (EpCAM; CD326) enables epidermal Langerhans cell motility and migration in vivo. Proc Natl Acad Sci USA 109: E889-E897, 2012.

14. Jaggupilli A and Elkord E: Significance of CD44 and CD24 as cancer stem cell markers: an enduring ambiguity. Clin Dev Immunol 2012: 708036, 2012.

15. Murai T, Maruyama Y, Mio K, Nishiyama H, Suga M and Sato C: Low cholesterol triggers membrane microdomain-dependent CD44 shedding and suppresses tumor cell migration. J Biol Chem 286: 1999-2007, 2011.

16. Zarrabi K, Dufour A, Li J, et al: Inhibition of matrix metalloproteinase 14 (MMP-14)-mediated cancer cell migration. J Biol Chem 286: 33167-33177, 2011.

17. Kemper K, Grandela C and Medema JP: Molecular identification and targeting of colorectal cancer stem cells. Oncotarget 1: 387-395, 2010.

18. Schulenburg A, Cech P, Herbacek I, Marian B, Wrba F, Valent P and Ulrich-Pur H: CD44-positive colorectal adenoma cells express the potential stem cell markers musashi antigen (msil) and ephrin B2 receptor (EphB2). J Pathol 213: 152-160, 2007.

19. Strauss R, Li ZY, Liu Y, et al: Analysis of epithelial and mesenchymal markers in ovarian cancer reveals phenotypic heterogeneity and plasticity. PLoS One 6: e16186, 2011.

20. Belov L, Zhou J and Christopherson RI: Cell surface markers in colorectal cancer prognosis. Int J Mol Sci 12: 78-113, 2010.

21. Wang SJ and Bourguignon LY: Role of hyaluronan-mediated CD44 signaling in head and neck squamous cell carcinoma progression and chemoresistance. Am J Pathol 178: 956-963, 2011.

22. Kuhn S, Koch M, Nübel T, et al: A complex of EpCAM, claudin-7, CD44 variant isoforms, and tetraspanins promotes colorectal cancer progression. Mol Cancer Res 5: 553-567, 2007.

23. Marhaba R, Klingbeil P, Nuebel T, Nazarenko I, Buechler MW and Zoeller M: CD44 and EpCAM: cancer-initiating cell markers. Curr Mol Med 8: 784-804, 2008.

24. Dylla SJ, Beviglia L, Park IK, et al: Colorectal cancer stem cells are enriched in xenogeneic tumors following chemotherapy. PLoS One 3: e2428, 2008.

25. Biddle A, Liang X, Gammon L, Fazil B, Harper LJ, Emich H, Costea DE and Mackenzie IC: Cancer stem cells in squamous cell carcinoma switch between two distinct phenotypes that are preferentially migratory or proliferative. Cancer Res 71: 5317-5326, 2011.

26. Münz M, Murr A, Kvesic M, et al: Side-by-side analysis of five clinically tested anti-EpCAM monoclonal antibodies. Cancer Cell Int 10: 44, 2010.

27. Bezan A, Hohla F, Meissnitzer T, et al: Systemic effect of catumaxomab in a patient with metastasized colorectal cancer: a case report. BMC Cancer 13: 618, 2013. 